\title{
Study of Quantitative and Qualitative Characteristics of Nickel Clusters and Semiconductor Structures
}

\author{
Elyor Bahriddinovich Saitov \\ Department of Electronics and Microelectronics, Tashkent State Technical University, Tashkent, Uzbekistan \\ Email: bahazeb@yandex.com
}

Received 27 April 2016; accepted 24 May 2016; published 27 May 2016

Copyright (C) 2016 by author and Scientific Research Publishing Inc. This work is licensed under the Creative Commons Attribution International License (CC BY). http://creativecommons.org/licenses/by/4.0/ (c) (i) Open Access

\begin{abstract}
The possibility of building of clusters of impurity atoms of $\mathrm{Ni}$ in silicon and controlling their parameters is currently investigated in the present research article. Our group develops a special technique for doping, the so-called "low-temperature doping" of semiconductors. This method of doping is based upon the diffusion process which is carried out in stages by gradually increasing temperature ranging from room temperature to the diffusion temperature.
\end{abstract}

\section{Keywords}

Single Crystalline Silicon, Nanoscale Structures, Self-Organization of Clusters of Impurity Atoms, Ni Clusters

\section{Main}

By using an atomic force microscope, one can obtain images as of physical objects (surfaces of solids), so much as of biological and chemical units (viruses and bacteria, atoms and molecules). Resolution of such microscopes sometimes reaches down the nanometer scale that allows us to observe individual atoms. AFM can do more than that. By using AFM, one can study the interaction of two objects, i.e. measure the force of friction, elasticity, adhesion, and move individual atoms across the surface, as well as depose and remove them from any surface.

Building the clusters of impurity atoms in the crystal lattice tends to be one of the advanced and convenient techniques of producing semiconductor nanostructures. This technique in compare to other techniques has the following advantages: allows forming nanoscale structures in the entire bulk of the crystal, allows regulating their concentration, structure and composition, as well as forming magnetic, multiply charged clusters. The above features of nanoclusters of impurity atoms can help regulate fundamental parameters of the material, and 
create entirely new materials with nanoscale structures. This paper presents original results on the kinetics of the formation of clusters of impurity atoms. The study shows that almost all impurity atoms can form clusters in the crystal lattice.

The interference technique does consist in obtaining information about the object by shaping in the image plane of corresponding intensity distribution and phase of optical radiation transferred through the object or reflected by an object. The technique of interference is used to control:

- Class of cleanliness of processing of surface of the substrate;

- Depth of scratches and etching steps;

- Depth and width of dividing grooves of silicon structures with dielectric insulation;

- Geometrical sizes of elements of structures of microchips;

- Thickness of photoresist;

- Levels of two surfaces designed for connection;

- Thickness of epitaxial layers, etc.

Researchers nowadays pay a special attention to nanoparticles with properties that differ from properties of bulk materials. In these view, nanoparticles on $\mathrm{Ni}$ atoms represent a certain interest among researchers.

The choice of the impurity atom is preconditioned by the fact that firstly, its solubility and the diffusion coefficient in silicon is comparatively higher than that of other elements of the Fe group, and secondly, Ni will most probably turn out to be one of the most important metals for the semiconductor industry in the near future.

Researchers at the Department of "Electronics and Microelectronics" of the Tashkent State Technical University develop a technique for obtaining and study of efficient solar cell on the basis of impurity atoms of micro and nanostructures in silicon.

Surfaces of the samples are investigated by using Infrared Microscope INFRA-I at the laboratory of the Department of Electronics and Microelectronics of Tashkent State Technical University (Figure 1). In samples heat treated at $\mathrm{T}=700^{\circ} \mathrm{C}$ for one hour, we have been able to witness uniformly dispersed clusters of Nickel atoms of little dimensions with sufficient density of $10^{5} \div 10^{6} \mathrm{~cm}^{-2}$. In samples heat-treated at $\mathrm{T}=700^{\circ} \mathrm{C}$ and $\mathrm{T}$ $=650^{\circ} \mathrm{C}$ for 6 hours and 10 hours, respectively, we have been able to determine that as time of annealing increases, so the size of clusters, whereas their density decreases.

As shown in [1] [2] in conditions of low temperature and multi-stage doping of silicon, Nickel atoms in the lattice tend to gather in clusters. One can vary conditions of doping and subsequently can manage dimensions of such clusters in the wide range of $0.1 \div 5$ microns. Such clusters of $\mathrm{Ni}$ atoms are distributed throughout the crystal lattice (Figure 1), their density, depending on alloying conditions ranges from $N_{s}=10^{6} \div 10^{7} \mathrm{~cm}^{-2}$ and their concentration is $N_{v}=10^{10} \div 10^{12} \mathrm{~cm}^{-3}$, respectively.

By using microprobe analysis, we have been able to determine the composition of clusters, which mainly consists of atoms of Nickel ( $50 \div 60 \%)$, silicon $(25 \div 30 \%)$ and oxygen $(\sim 10 \div 15 \%)$. Meanwhile, such a cluster manifests metallic conductivity (Figure 2).
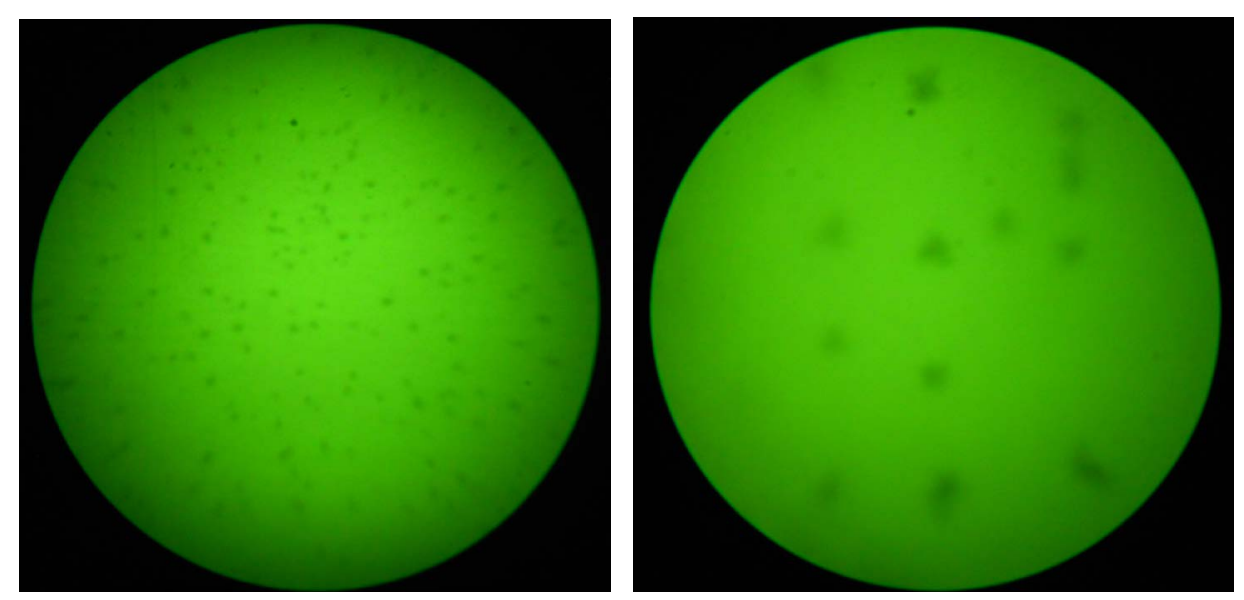

Figure 1. Distribution of clusters of Ni atoms on silicon sample surface (INFRA-I-infrared microscope photo depict). 


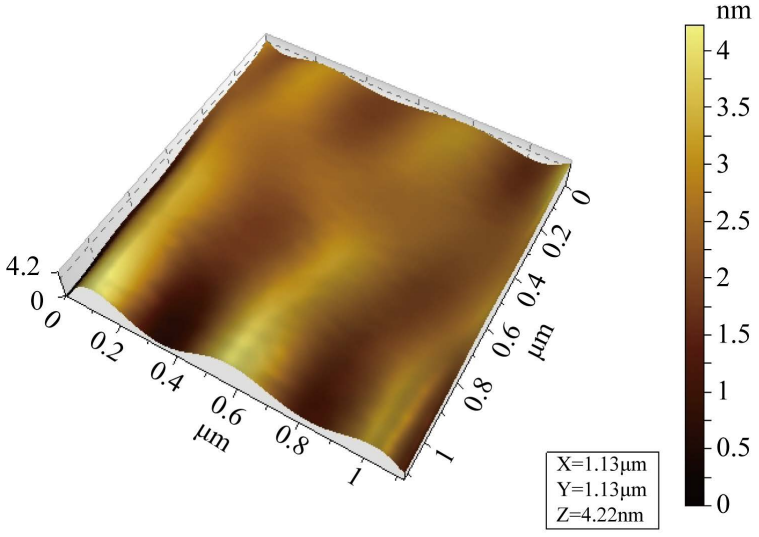

(a)

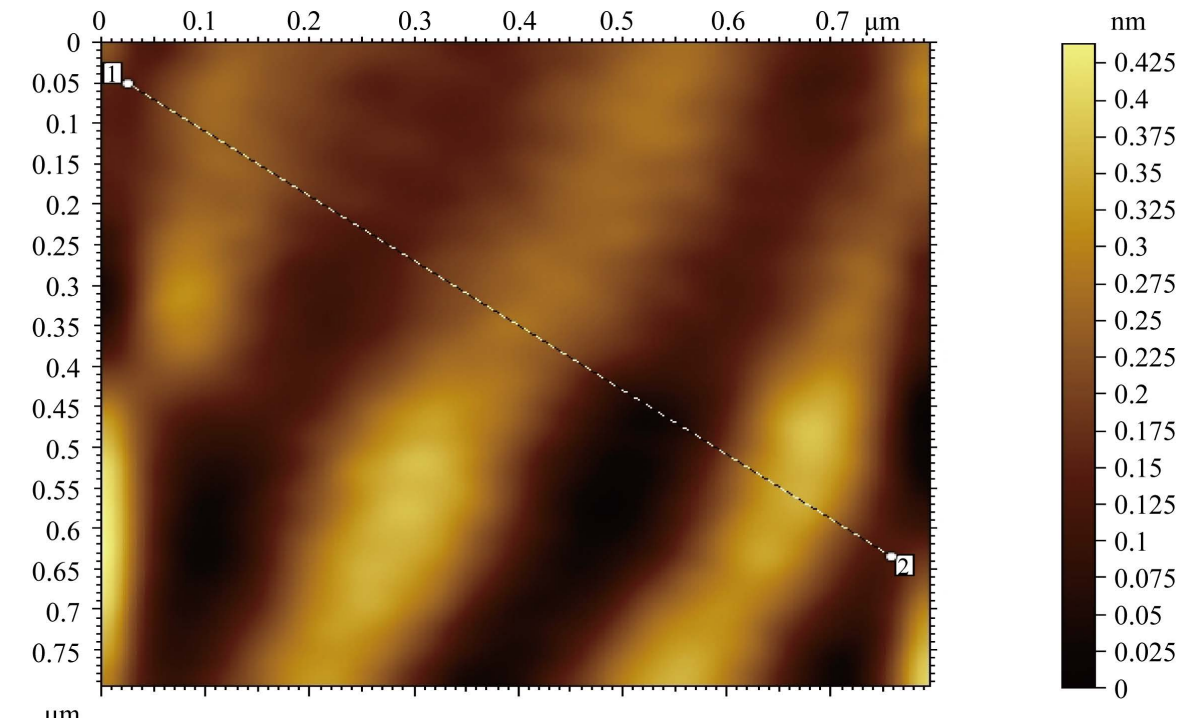

Cursor 1

$\mathrm{X}=0.0233 \mu \mathrm{m}$

$\mathrm{Y}=0.0482 \mu \mathrm{m}$

Cursor 2

$\mathrm{X}=0.758 \mu \mathrm{m}$

$\mathrm{Y}=0.635 \mu \mathrm{m}$

$\mathrm{Z}=0.145 \mu \mathrm{m}$

$\mathrm{Z}=0.132 \mu \mathrm{m}$

Horizontal distance $\quad 0.939 \mu \mathrm{m}$

Height difference $\quad 0.013 \mathrm{~nm}$

Oblique distance $\quad 0.939 \mu \mathrm{m}$

(b)

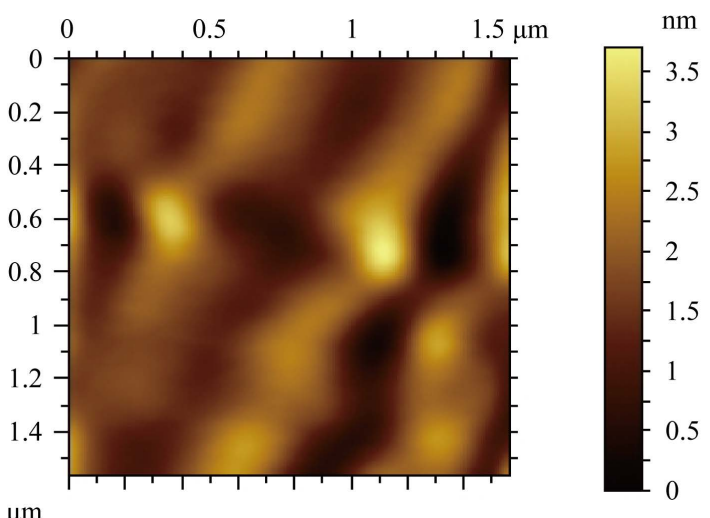

(c) 


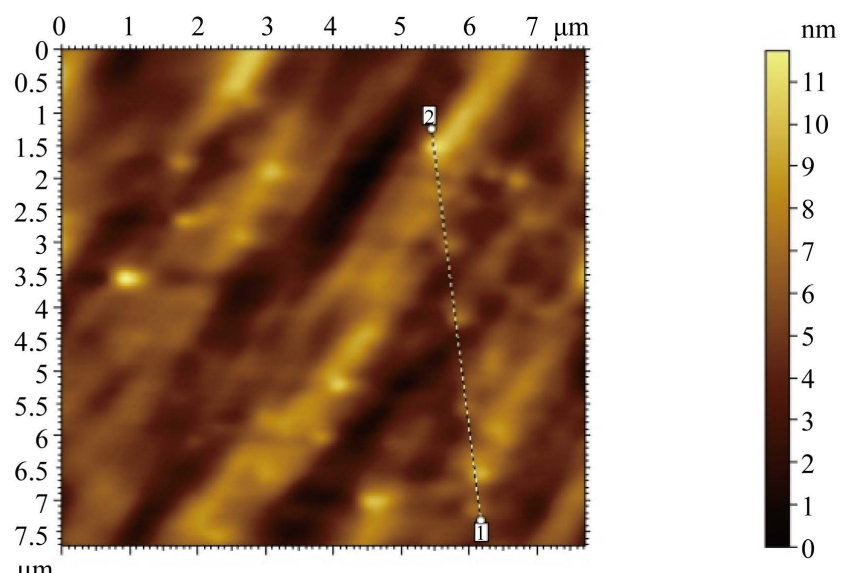

$$
\begin{aligned}
& \begin{array}{ll}
\text { Cursor 1 } & \text { Cursor 2 } \\
X=6.17 \mu \mathrm{m} & X=5.45 \mu \mathrm{m}
\end{array} \\
& \mathrm{Y}=7.32 \mu \mathrm{m} \quad \mathrm{Y}=1.22 \mu \mathrm{m} \\
& \mathrm{Z}=5.34 \mu \mathrm{m} \quad \mathrm{Z}=5.96 \mu \mathrm{m}
\end{aligned}
$$

Horizontal distance $6.14 \mu \mathrm{m}$

Height difference $0.618 \mathrm{~nm}$

Oblique distance $\quad 6.14 \mu \mathrm{m}$

(d)

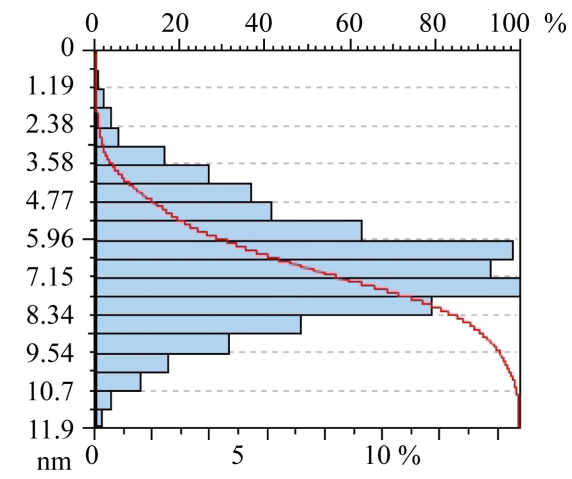

(e)

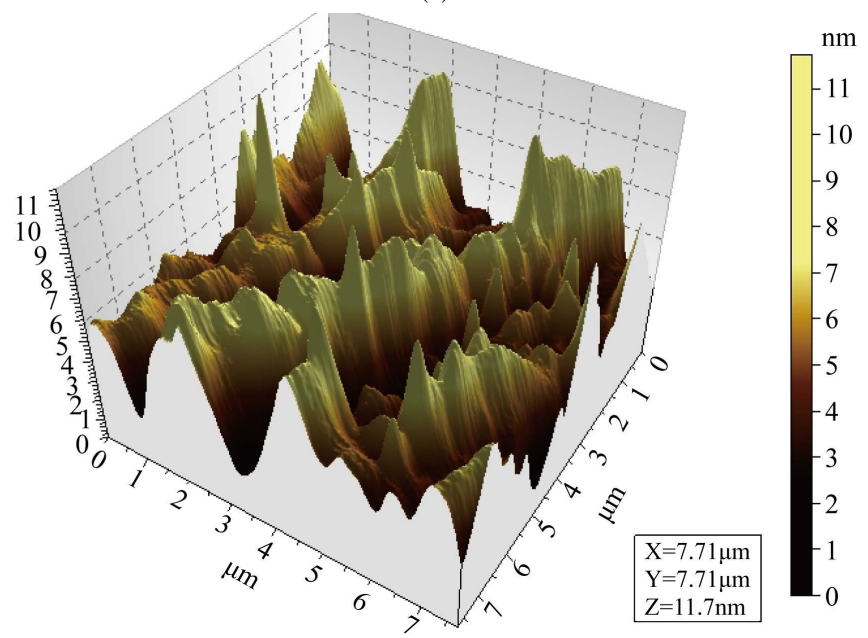

(f)

Figure 2. Distribution of Ni clusters on Si surface (AFM). (a) - silicon sample excluding Ni clusters; (b) —annealing duration 1 hour; (c)—annealing duration 2 hours; (d) - annealing duration 3 hours; (e)-integral and differential distribution of Ni clusters in silicon; (f) - distribution of Ni clusters in silicon. 
Table 1. Parameters of clusters of nickel as a function of temperature.

\begin{tabular}{|c|c|c|c|c|c|c|c|c|c|c|c|}
\hline Temperature, ${ }^{\circ} \mathrm{C}$ & 1250 & 1150 & 1100 & 1050 & 1000 & 900 & 800 & 700 & 650 & 600 & 500 \\
\hline Solubility, см$^{-3}$ & $4 \times 10^{17}$ & $2 \times 10^{17}$ & $6 \times 10^{16}$ & $2.6 \times 10^{16}$ & $1.4 \times 10^{16}$ & $1.4 \times 10^{15}$ & $8 \times 10^{14}$ & $2 \times 10^{13}$ & $3.7 \times 10^{12}$ & $7 \times 10^{11}$ & $1.3 \times 10^{9}$ \\
\hline $\begin{array}{l}\text { Coefficient of } \\
\text { diffusion, } \mathrm{cm}^{-2} / \mathrm{s}\end{array}$ & $5.7 \times 10^{-5}$ & $4 \times 10^{-5}$ & $2.8 \times 10^{-5}$ & $2.5 \times 10^{-5}$ & $2.2 \times 10^{-5}$ & $2 \times 10^{-5}$ & $10^{-5}$ & $8 \times 10^{-6}$ & $6 \times 10^{-6}$ & $4 \times 10^{-6}$ & $2 \times 10^{-6}$ \\
\hline $\begin{array}{l}\text { Coefficient of } \\
\text { saturation }\end{array}$ & 0 & 2 & 7 & 15 & 29 & 290 & 500 & $2 \times 10^{4}$ & $10^{5}$ & $6 \times 10^{5}$ & $2.6 \times 10^{8}$ \\
\hline $\begin{array}{l}\text { Time required for } \\
\text { building clusters, } \\
\text { sec. }\end{array}$ & - & $5 \times 10^{-4}$ & $7 \times 10^{-2}$ & $1.6 \times 10^{-2}$ & $7.8 \times 10^{-1}$ & 7.5 & 30 & $2.5 \times 10^{3}$ & $4 \times 10^{4}$ & $4 \times 10^{5}$ & $5 \times 10^{8}$ \\
\hline $\begin{array}{l}\text { Concentration of } \\
\text { clusters }\end{array}$ & - & $2 \times 10^{17}$ & $6 \times 10^{16}$ & $2.6 \times 10^{16}$ & $1.4 \times 10^{16}$ & $1.4 \times 10^{15}$ & $8 \times 10^{14}$ & $2 \times 10^{13}$ & $3.7 \times 10^{12}$ & $7 \times 10^{11}$ & $1.3 \times 10^{9}$ \\
\hline Size & - & $\begin{array}{l}\text { Molecule of } \\
\mathrm{Ni}_{2}\end{array}$ & $0.5 \mathrm{~nm}$ & $\sim 1 \mathrm{~nm}$ & $1.5 \div 2 \mathrm{~nm}$ & $10 \mathrm{~nm}$ & $\begin{array}{c}15 \div 20 \\
\mathrm{~nm}\end{array}$ & $>150 \mathrm{~nm}$ & $\sim 1 \mathrm{mic}$ & $\begin{array}{l}\sim 3 \div 5 \\
\text { mic }\end{array}$ & $>10$ mic \\
\hline
\end{tabular}

One can assume that each such cluster creates a micro-size Schottky diode. Meanwhile such Schottky diodes are present throughout the bulk, which means one can firstly, obtain the "buried-in-the bulk" Schottky diodes with a sufficiently high concentration, and secondly, they represent almost perfect structures, without surface states.

Table 1 contains theoretical calculations showing various characteristics of clusters in silicon alloyed with nickel, i.e. their size, concentration, and quantity of atoms inside the cluster.

As it is seen from the Table 1, by varying process conditions, one can obtain clusters with dimensions ranging from $0.5 \mathrm{~nm}$ to 100 microns and with concentration of $10^{12}-10^{16} \mathrm{~cm}^{-3}$. Meanwhile the number of atoms in such clusters may vary from ten to almost million atoms, which means one can shape clusters with required parameters.

Interesting results were obtained at additional low-temperature heat treatment at $\mathrm{T}=700^{\circ} \mathrm{C}$. Thus, ordering of impurity clusters of nickel atoms in silicon occurs as a function of time of heat treatment.

The results of investigations indicate that such ordering of clusters of impurity atoms occurs throughout the entire bulk of the crystal. So far, no physical mechanism is available to explain this phenomenon. However, the process of ordering of clusters leads us to conclude that there is the possibility of diffusion of clusters with relatively higher ration of diffusion. However to prove the above results one needs to carry out detailed thorough research and investigations. It was figured out that as the temperature of additional heat treatment increases the ordering of clusters collapses again and they become evenly distributed again. Preliminary investigations in I-Vcurve of cluster-Si by microprobe have shown that such a structure is characterized by almost ideal I-V-curve with very little reverse current and it starts to manifest sensitiveness to irradiation and temperature.

Over the past few years, there has been a widespread interest among experts in the field of nanotechnology and nanoelectronics all over the world in the technology of self-organizing impurity clusters with manageable structures and magnetic properties. In this respect one can note some interesting results related to implanting Co and $\mathrm{Ge}$ ions on $\mathrm{Si}$, ion implantation in other semiconductor materials [3] [4].

As we have noted earlier, our group developed a special technique for doping, the so-called "low-temperature doping" of semiconductors. This method of doping is based upon the diffusion process which is carried out in stages by gradually increasing temperature ranging from room temperature to the diffusion temperature [5] [6].

The study of photovoltaic properties of Schottky micro-diodes shows that such structures manifest sufficiently high photo-voltage at room temperature and, depending on the parameters of a cluster (size, location, depth and e.t.c.), $\mathrm{V}_{\text {idle }}$ can reach $100 \div 200 \mathrm{mV}$ ( $\mathrm{I}_{\text {short circuit }} \sim 2 \times 10^{-6}$ A). The above data evidences that on the basis of Si samples where density of microstructures equals $N \sim 10^{5} \div 10^{6} \mathrm{~cm}^{-2}$ and by connecting them in series or in parallel one can eventually obtain an integrated photocell. By using $50 \%$ of the given area one can obtain $39.2 \times$ $10^{8}$ Schottky micro-diodes each of which would perform as an individual solar cell.

\section{References}

[1] Орлов, А.М., Явтушенко, И.О., Боднарский, Д.С. and Уфаркина, Н.В. (2013) Получение металлических наночастиц из водных растворов в плазме искрового разряда. ЖТФ, 83, Вып. 9 
[2] Орлов, А.М., Явтушенко, И.О. аnd Боднарский, Д.С. (2013) Трансформация компонентов воздушной атмосферы в зоне искрового разряда при анодной поляризации нависающего над раствором металлического электрода. ЖТФ, 83, 54-60.

[3] Бахадырханов, М.К., Исамов, С.Б., Зикриллаев, Н.Ф. and Хайдаров, К. (2013) Наноразмерная варизонная структура в кремнии с многозарядными нанокластерами. Микроэлектроника, 42, 444-446. http://dx.doi.org/10.7868/S0544126913060033

[4] Герасименко, Н.Н., Протасенко, В.В., Вернер, И.В. and Троицкий, В.Ю. (2000) Самоорганизация поверхности кремния при ионном синтезе дисилицида кобальта. Известия Вузов, Электроника, 80.

[5] Пархоменко, Ю.Н., Белогорохов, А.И., Герасименко, Н.Н. and Иржак, А.В. and Лисаченко, М.Г. (2004) Свойства самоорганизованных SiGe-наноструктур, полученных методом ионной имплантации. ФТП, 38, 593-597.

[6] Бахадырханов, М.К., Аюпов, К.С., Илиев, Х.М., Мавлонов, Г.Х. аnd Саттаров, О.Э. (2010) Влияние электрического поля, освещенности и температуры на отрицательное магнетосопротивление кремния, легированного по методу низкотемпературной диффузии. ПЖТФ, 36, 11-19. 